\title{
Høyeste prioritet
}

Det er mange måter å bruke ressurser på. For å prioritere riktig er det viktig å beregne helsegevinsten, men noe mangler i regnestykkene.

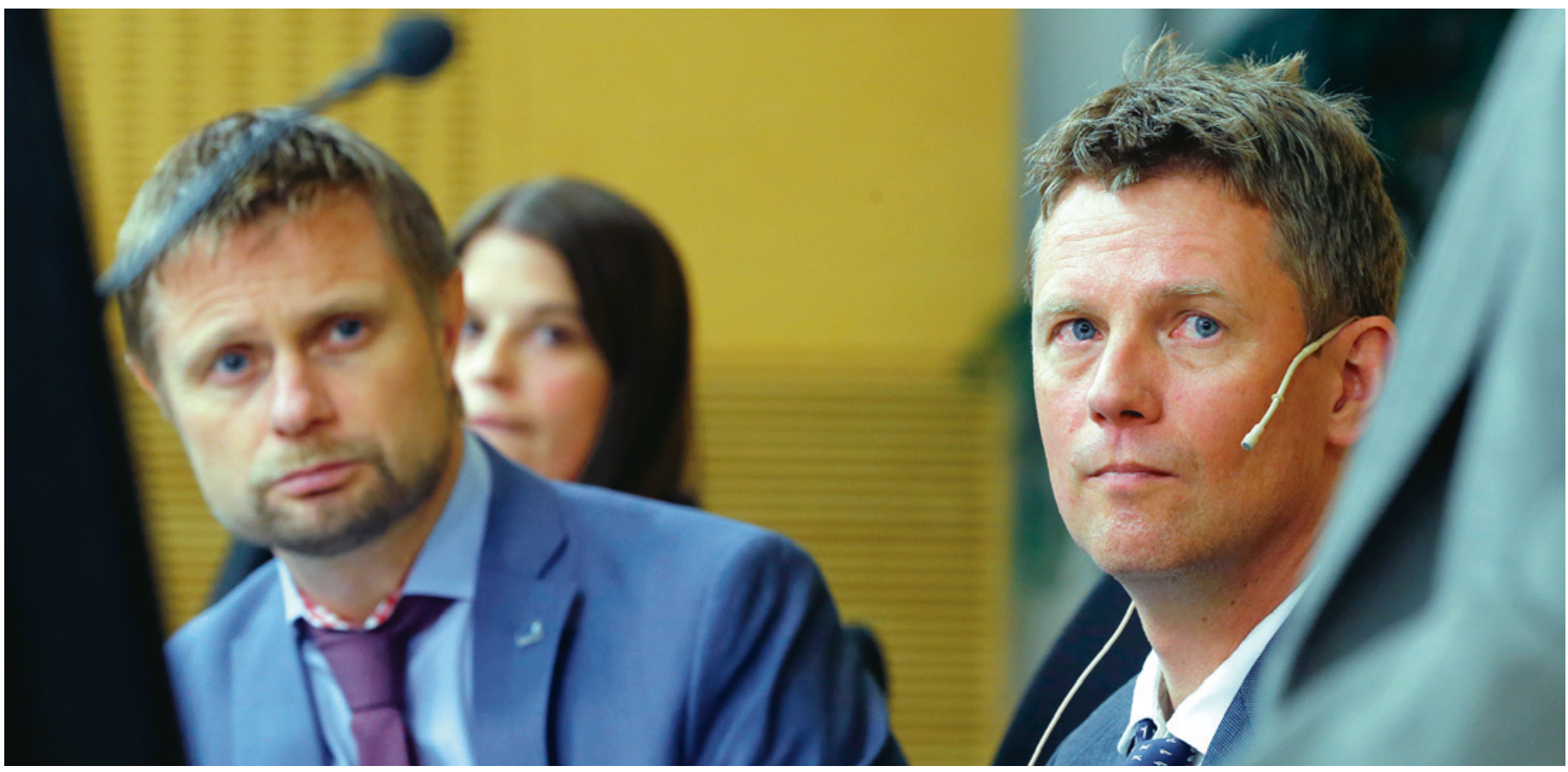

Prioriteringsutvalget ved Ole Frithjof Norheim overleverte 12. november 2014 sin utredning om prioritering i helsetjenesten til helse- og omsorgsminister Bent Høie. Foto: Terje Pedersen/NTB scanpix

Mange viktige, moralske og faglige problemstillinger kom opp i kjølvannet av Norheimutvalgets innstilling (1). To av de viktigste temaene var hva god prioritering er, og hvordan legene kan eller bør bidra. Disse spørsmålene er selvsagt av stor betydning for de samlede prioriteringene, men et annet $-\mathrm{og}$ like vesentlig - tema har knapt vært framme i diskusjonen. Det gjelder spørsmålet om nytten av styringssystemet selv.

Norsk helsevesen har, som de fleste i den vestlige verden, gått gjennom en rekke reformer de siste tre tiårene. Endringer i finansieringsformer og styringsmodeller er de viktigste, som sykehusreformen, fastlegereformen og stykkprisfinansiering. Hver reform har selvsagt også brukt ressurser fra helsebudsjettet - til utredninger, komiteer, endret lovverk og finansieringssystem, endringer i og utvidelse av helseforvaltningen sentralt, og endringer og utvidelser i forvaltningsfunksjoner lokalt.

Enhver beslutning om en bestemt måte å bruke ressurser på har en hake - nemlig de alternativene vi ikke valgte. God prioritering innebærer at tapet ved det vi ikke gjorde, er minst mulig, med andre ord at alternativkostnaden er så lav som mulig. Når vi velger å prioritere ressurser til forvaltning eller reformer, bør det begrunnes med at alternativkostnaden er lav.

Norske helsemyndigheter har vært opptatt av prioriteringsspørsmålet helt siden Lønning 1-utredningen kom i 1987. Men så vidt jeg vet, har spørsmålet om alternativ-

\section{«God prioritering}

innebærer at tapet

ved det vi ikke gjorde, er minst mulig»

kostnadene ved ressursbruken i forvaltningen aldri vært nevnt, eller alternativkostnadene ved endringer i styringsstrukturer og andre reformer. En analyse av spørsmålet om hvordan vi prioriterer i norsk helsetjeneste er ufullstendig uten at denne ressursbruken er med i regnestykket. Det avgjørende spørsmålet er om vi har grunn til å mene at dette er bedre ressursbruk enn om ressursene ble brukt på andre måter.

Det er imidlertid ikke bare den ufullsten- dige beregningen som er et problem ved denne unnlatelsen - også tilbakemeldingen til aktørene i styringssystemet blir mangelfull. Når helsemyndighetene utformer styringssystemet, tenker man at det må representere tydelige føringer for å sikre mest mulig helseforbedring for ressursbruken, rettferdig fordelt. Når aktiviteten til forvaltningen selv imidlertid ikke er en del av dette regnestykket, får vi ikke de rette incentivene for denne delen av helsetjenesten. Administrasjons- og endringskostnader blir undervurdert. Sanksjonene mangler, og ansvarsforholdene blir uklare - noe som i de fleste systemer er en oppskrift på sløsing.

En ny stortingsmelding om prioriteringer i helsetjenesten er nå på trappene. Å beregne den helsemessige nytten av ressursbruken på systemnivå bør nå få høyeste prioritet.

\section{Berit Bringedal}

LEFO - Legeforskningsinstituttet

\section{Litteratur}

1. Norges offentlige utredninger. Åpent og rettferdig. Prioriteringer i helsetjenesten. NOU 2014: 12. Oslo: Departementenes sikkerhets- og serviceorganisasjon, Informasjonsforvaltning, 2014. 